\title{
Exploring Campbell hero's journey in the light of two selected epic poems: Beowulf and The Mwindo epic
}

\section{Bazimaziki Gabriel}

University of Rwanda, College of Education, Department of Humanities and Language Education

Received: 18 Oct 2020; Received in revised form: 10 Nov 2020; Accepted: 11 Nov 2020; Available online: 17 Nov 2020

"When the will defies fear, when duty throws the gauntlet down to fate, when honor scorns to compromise with death - that is heroism”(Robert Green Ingersoll)

\begin{abstract}
Through various genres, literature reveals how many cultures hold stories about the triumph of great men as depicted in epic and myth, two genres which hold a big space in dealing with human heroic exploits and superhuman deeds. Those genres embed the consummation of all aspects of society and oral traditions. In this study, Campbell's theory of heroic journey outline and Otto Rank's theory of a mythic hero were used to analyse the protagonists in two epics namely The Mwindo Epic from Africa, and Beowulf from western civilization. Discussion revealed that the two epics reflect the hero's journey divided into three main sections videlicet separation, initiation and return. The two heroes' journeys depict their power for each. It was also found that the two stories are concerned with human heroic exploits and superhuman deeds which range the protagonists not only among epic characters but also other bygone heroes led by destiny. agains. The two epics teach humanity that one's genuine heroism lies in their persistency.
\end{abstract}

Keywords-Epic, myth, supernatural, quest, hero, Campbell, Otto Rank, Beowulf, Mwindo.

\section{BACKGROUND}

Life, death, injustice, generosity, heroism, immortality and the supernatural range among the recurrent themes discussed in literature. Literary studies contend that almost every culture has its stories of human beings who triumph over fate, gods or natural disaster; not because they are always strong but often because of their personal attributes, including without limitation to courage and cleverness. Myth and epic are no exception as they tell stories about loyalty and betrayal, heroism and cowardice, life and death, love and rejection among other things. Myth and epic are two literary subgenres that are not easy if not impossible to distance as both are heroic narratives whose protagonists are equipped with both human and superhuman powers - and are led by destiny, which allow them to perform extraordinary wanders in their quest for their identity, along their fight for a cause, for justice they are often times denied. Mwindo was denied by Shemwindo, his father who did not wish to beget a son any more, but Mwindo proved him that "A father cannot be a father without a son, and a son cannot be a son without a father" and consequently made that father to accept him as his son despite all the attempts to end his life but in vain as he (Mwindo) said to him "You must be my father so I can be your son." Savitri is a similar exceptional figure. She is a daughter of a long - before- childless king Aswapathy who lived in Madra country. Now that she has grown mature, her father sends her to find a partner for herself as he says; "Why don't you go ahead and find a partner of yourself?" and then undertakes that hazardous quest. Shaka cannot be expelled from these rejected but saved characters. Kunene (1979) accounts that his father Sezangakona perpetrated injustice against him until he wants to kill him. Beowulf, the hero of an 
epic of Old English, cannot be left out. The poem Beowulf is a partly historical narrative describing a set of events set in Scandinavia. Its hero, Beowulf, is the biggest presence among the warriors in the land of the Geats, a territory situated in southern Sweden. Beowulf crosses the sea to the land of the Danes in order to clear their country. He was called to fight Grendel, a dragon and a man-eating monster that had devastated Horthgar's kingdom (Heaney, 2000). For both of these two epics attracted readers' attention, the heroic journey in each was explored by measuring the protagonists in the light of Campbell hero's journey and Otto Rank's theory of hero-myth. Simply put, Mwindo, the hero in the Nyanga epic is measured to Beowulf, the hero of the Old English epic.

\section{AIM OF THE STUDY}

Literary studies vary from critic to critic and their interests for each. Some studies focus on central characters and themes affecting them while others look into how language is used in a literary works or the like. In this study, the aim was to carry out a literary analysis by exploring epics' protagonists while identifying their heroic deeds. Put another way, the purpose of this study was to discuss heroism and the supernatural in two selected poems namely The Mwindo Epic and Beowulf.

\section{Study questions}

This study is a literary analysis that sought to explore selected epic poems using Campbell's heroic journey framework and Otto Rank's Theory of Mythic hero. The researcher wanted to find out answers for the following questions: (1) How far are myths and epics related literary genres? (2)To what extent do Campbell's heroic journey and Otto Rank's hero -myth theory apply in the study of Beowulf and The Mwindio epic? and (3) what authorial messages are conveyed through the characters of Beowulf and Mwindo? In the light of these study questions, two theories discussed in the following sections played an invaluable part.

\section{Mythic and epic hero: Some literature reviewed}

An epic is generally a long narrative poem recounting in elevated style the deeds of a legendary hero, especially one originating in oral folk tradition. The epic tradition has been part of many different cultures throughout human history (Bazimaziki, 2017) and has held an important space in the literary arena. For example, the small Nyanga tribe (in Congo) possesses a highly diversified oral rich literature of this kind including the Mwindo Epic (Biyebuyck \& Mateene, 1969).
Literary critics believe that epics are cultural monuments which preserve the cultural values and customs (Rummel, 2002) and create into the readers' mind a feeling of belonging and pride (Bieyebuck, 1978). Epic is also referred to as the consummation of all social aspects and oral traditions (Scheub, 2012). In many literatures, studies on heroic epics have not had as wide ground as other genres but heroism has attracted an interest of many critics who deal with exceptional characters on a quest for triumph and elixir, power and the boon depicting mythic heroes often referred to as legendary heroes.

In literature, myths and epics are not easy to distance. Both are concerned with heroic highly ranked personalities described by human and supernatural achievements. They are characterised by particular traits, and are extraordinary figures found in various cultures at different times. Myth is generally regarded as a traditional story concerned with early history of a given people or explaining a natural or social phenomenon, typically involving the natural or supernatural beings or events. Cousineau(1990) believes that the great mystery that myths deal with is the essence of life and adds that a typical myth is a kind of covenant between the animal and human world. Clyde (2000) asserts that myths convey the perennial wisdom of humanity: the creation of the world, the hero's journey, our relationship with nature, death, and resurrection. Using Mwindo, the hero in the Congo's epic, the author posits that these stories involve the sacred warriors who reflect the path each person must travel to discover their true destiny through a quest orchestrated in three main movements that is, departure, initiation and return. Although not conceived and born as a normal human being, Mwindo is a human child born from the sexual intercourse but through his mother's medius (Biyebuyck \& Mateene, 1969). He is son of a chief, rejected but ultimately is accepted by his father and becomes chief. Thus, the mythic hero may be historical or fictional as well shown in Abrahams (1999:170) that

“... a myth is one story in a mythology - a system of hereditary stories of ancient origin which were once believed to be true by a particular cultural group, and which served to explain (in terms of the intentions and actions of deities and other supernatural beings) why the world is as it is and things happen as they do, to provide a rationale for social customs and observances, and to establish the sanctions for the rules by which people conduct their lives. [...]If the protagonist is a human being rather than a supernatural being, the traditional story is usually not called a myth 
but a legend. If the hereditary story concerns supernatural beings who are not gods, and the story is not part of a systematic mythology, it is usually classified as a folktale"

Looking at the above words, one can put it that myth is concerned with human life, both human and supernatural exploits, and the origin of things. Toliver (2014) explicates it well that myth assigns gods both cyclonic power and regularity much as nature itself mixes springtime growth, crops, irregular floods and storm. It is said that after Mwindo was thrown away into the deep of the river, earth and heaven joined together because of a heavy rain which lasted for seven days. Inherently, the epic poem is not far distant from the above situation. As concerned with battles and royal issues, epics reveal how the divine and human forces operate concurrently and how the superhuman power interferes in human affairs. In other words, human beings in epic stories are driven by forces which they cannot control. More so, they epic protagonists, in most of cases, are tied with fate and destiny that they are unable to alter or deviate. Abrahams(1999) says that epic or heroic poem is a long verse narration about a serious subject, told in a formal and elevated style, and centered on a heroic or quasi-divine figure on whose actions depends on the fate of a tribe, a nation, or (in the instance of John Milton's Paradise Lost) the human race. The author contends that these actions involve superhuman deeds in battle where gods and other supernatural being play an active part.

A mythic hero is a child of distinguished parents, usually a son of a king, whose origin is preceded difficulties such as the continence or prolonged bareness or secret intercourse of the parent (Rank qtd in Bazimaziki, 2017). Mwindo fits many of these characteristics. He was born unusually as he passed through his mother's navel. He said, "I am ready. I will not come out like other babies. I will come out through my mother's navel." This happened as we are told that "His mother lay in bed and the son came out through her navel. He jumped down and ran around the room. In his hand was a conga flyswatter, with a handle of wood and a swatter of buffalo tail" (Shepard, 2006. That is an exceptional birth which is beyond human belief especially that he walked as soon as he was born ('the-little-one-born-just-he-walked'). Hence, Mwindo ranges among mythic heroes. Savitri is not far distant from these features in that she is concerned with elevated parentage, and is an infant exposed to marvelous adventures or the like. To illustrate, Savitri was begot after her father, king Aswapathy had spent many years without having a progeny. Besides, myths and epics have meeting points in the sense that both are bent on the quest theme and the immortality of their heroes associated with the magical power. Mwi ndo's conga defeated his father who wanted to end his life. Further, many myths are anonymous and are of less historical background than epics whose historical backgrounds are known.

Thus, the two epics involved in this paper display some mythic and epic features including life and death. One will conclude here that the distinction between a mythic hero's journey and epic hero's is not easy to draw as they involve a blend of both human and supernatural plot for each.

\section{THEORIES AND METHOD}

This study compares two protagonists in two heroic epics. The discussion hinges concurrently on Joseph Campbell's "Hero's Journey" outline and Otto Rank's theory of mythic hero. The author's choice of these two theories in this paper was dictated by his particular interest in literary analysis involving the quest theme discussed in his early papers. Actually, Campbell advocates that the mythic hero generally participates in a cyclical journey or quest along which he faces adversaries whom he will defeat and return home transformed. The epic hero, he said, illustrates traits, performs deeds, and exemplifies certain morals that are valued by the society the epic originates from. We will find that this theory fits for the two heroes under discussion. Otto Rank's theory of mythic hero fits for this study too. According to this theory, HeroMyth is interpreted following eleven important features such as (1) hero is a child of distinguished parents( as are Savitri, Mwindo and Beowulf) (2) parents have previous difficulties(a case of Mwindo and Savitri) and the child birth is extraordinary, Mwindo being a good reference because, he climbed up into his mother's belly, then farther up toward her shoulder, descending down her arm where it was born through the preferred one's middle finger"( Clyde, 2000), (3)prophecy threatens father (4) baby is put into water in box(as happened to Mwindo), (5) baby is saved by animals or peasants and (6) baby is nursed by lowly woman(Mwindo being the most concerned as he was saved by her aunt, Iyangura), (8)hero finds parents, (9)hero takes revenge on father and (10)father acknowledges hero(Shemwindo now accepts to be father to Mwindo, a son he had refused and then rejected vainly long before), and lastly (11) hero is honored. For example, the Geats honoured Beowulfas the gentlest and the most gracious 
of of men, the kindest to his people, and the most desirous of renowned (Wright, 1957).

\section{Summary of "The Hero's Journey" Outline}

Campbell explores the theory of survived myths for thousands of years as they share a fundamental structure, which he called the monomyth. In a well-known quote from the introduction to The Hero with a Thousand Faces, Campbell summarized it by outlining stages along this journey. In a cogent summary, these stages may be organized in a number of ways, including division into three sections: Departure (sometimes called Separation), Initiation and Return. "Departure" deals with the hero venturing forth on the quest, "Initiation" deals with the hero's various adventures along the way, and "Return" deals with the hero's return home with knowledge and powers acquired on the journey as outlined on the figure below:

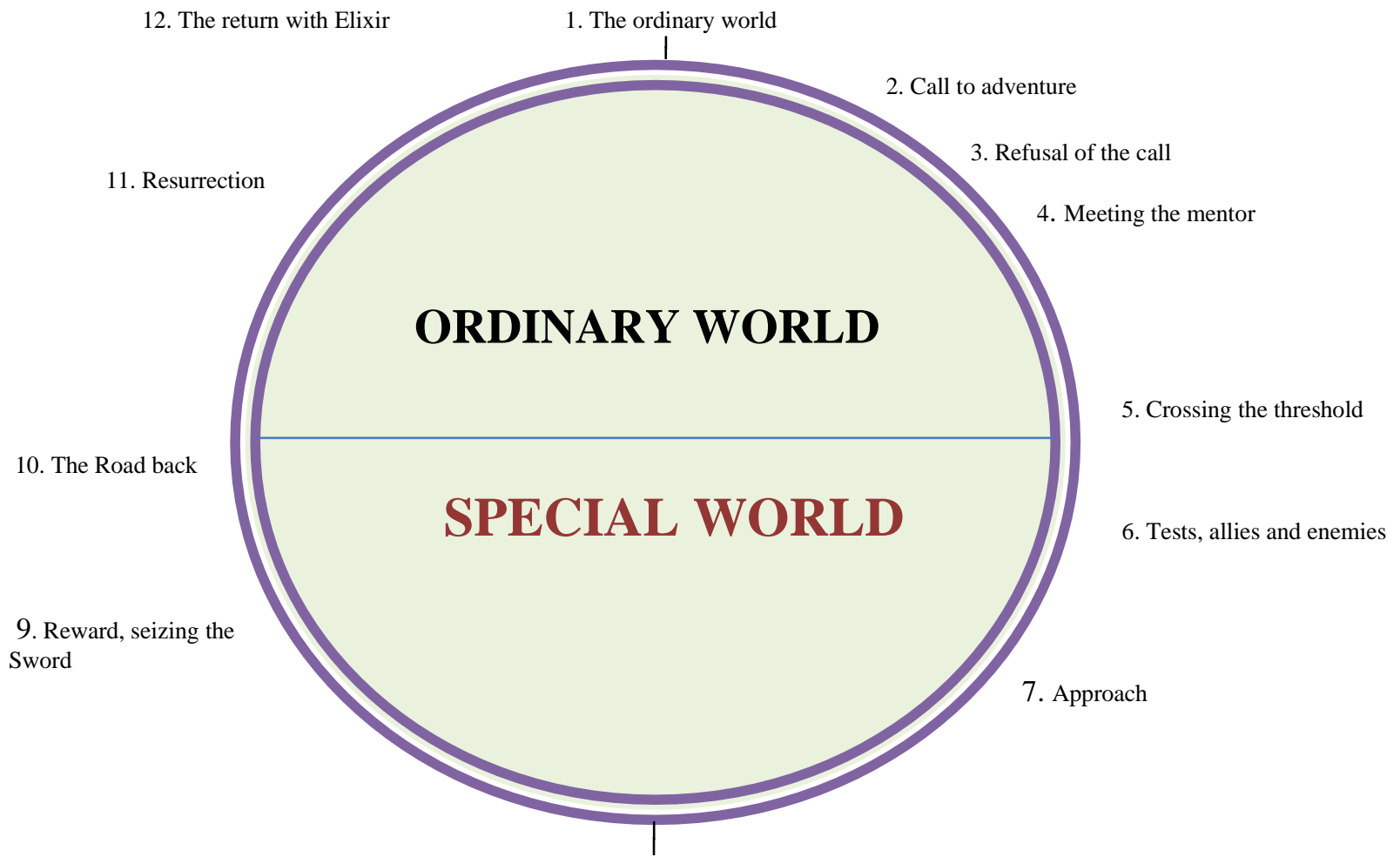

8. Ordeal, Death and Return

Fig.1: Campbell's Heroic journey outline (Adapted from Bazimaziki, 2017)

Actually, the hero is introduced in his ordinary world where he receives the call to adventure. He is reluctant at first to cross the first threshold where he eventually encounters tests, allies and enemies. He reaches the innermost cave where he endures the supreme ordeal. He seizes the sword or the treasure and is pursued on the road back to his world. He is resurrected and transformed by his experience and finally returns to his ordinary world with a treasure, boon, or elixir to benefit his world. Campbell's theory of Hero's journey fits for this study as it holds that epic core events lead to the birth of the hero, the hero's youth and exile, and the hero's return to conquer his nation from the enemy.

\section{DISCUSSION}

In this section, the stages of the hero's journey are discussed in the light of The Mwindo Epic and Beowulf. While Campbell advocates that the Hero's Journey is a pattern of narrative that appears in drama, storytelling, myth development or the like, for this study myth is more concerned than the rest. Not all the 
twelve stages fit the two stories hence those that do not match the situation in the epics under study were not given much space.

At stage one, the hero is introduced in his ordinary world before he is taken to a special world, new to a hero. This is the birth of the hero. Ordinarily, human life journey starts at birth time where a child is taken to the world of ordinary people. To start with Mwindo, his father Shemwindo had called all his seven wives, his counselors and all his people and told them that "When a daughter marries, her family is paid a bride-price. But when a son marries, it is his family that pays it. So, all my children must be daughters. If any is a son, I will kill him" (Shepard, 2006). However, the story teller revealed that the child exceptional birth through his mother's navel would lead to his father's failure to kill him. We are told that "Mwindo was born laughing, speaking, and walking, holding a conga-scepter in his right hand and an ax in his left. He was born wearing a little bag of the spirit of Kahindo, the goddess of good fortune, slung across the left side of his back, and in that little bag there was a long rope" Clyde(2000). He is therefore identified himself as "the Little-one-born-just-hewalked." Concerning Beowulf, his birth is not described but Heaney (2000:28) says that he is a descendent from Hygelac's. Although his birth is not described in the poem, he is announcing his name among the Geats whom he is called to come for help. The hero says: The man whose name was known for courage, the Geat leader, resolute in his helmet, answered in return: "We are retainers from Hygelac's band. Beowulf is my name. If your lord and master, the most renowned son of Halfdane, will hear me out and graciously allow me to greet him in person, I am ready and willing to report my errand.

Following Campbell's heroic journey, stage two is concerned with the call to adventure. At this stage, the hero is presented with a problem, challenge or adventure. Each of the two heroes in this study is affected with this stage. Mwindo's initiation stage is concerned with his father's plan to kill him. $\mathrm{He}$ is called to claim his right. Beowulf is called to fight a man - eating monster. He is tasked by king of Geats as shown in these words: " Hrothgar, protector of Shieldings, replied: "I used to know him when he was a young boy. His father before him was called Ecgtheow. Hrethel the Geat gave Ecgtheow his daughter in marriage. This man is their son, here to follow up an old friendship. [...] Now Holy God has, in his goodness, guided him here to the West-Danes, to defend us from

ISSN: $2456-7620$

https://dx.doi.org/10.22161/ijels.56.3
Grendel. This is my hope; and for his heroism I will recompense him with a rich treasure." (Heaney, 2000: 28)

It follows that the hero refuses the call at stage three. Often at this point the hero balks at the threshold of adventure facing the greatest fear of the unknown. Concerning Beowulf, Heaney (2000:29) says that he accepted the call by declaring that he will fight Grendel as shown in these lines: "Now I mean to be a match for Grendel, settle the outcome in single combat. And so, my request, O king of Bright-Danes, dear prince of the Shieldings, friend of the people and their ring of defense, my one request is that you won't refuse me, who have come this far, the privilege of purifying Heorot, with my own men to help me, and nobody else." As the journey progresses, the author shows that Beowulf's is determined to defeat Grendel as shown from line 559 to 606. He said; "He knows he can trample down you Danes to his heart's content, humiliate and murder without fear of reprisal. But he will find me different. I will show him how Geats shape to kill in the heat of battle. Then whoever wants to may go bravely to mead, when morning light, scarfed in sun-dazzle, shines forth from the south and brings daybreak to the world." (p.41)

Similarly, Mwindo accepts the call since he was driven by fate that he could not fathom. He is now on his journey led by superhuman forces. Clyde (2000) reveals how "The counselors dug the grave and placed him in that grave. But Mwindo howled, saying, "O my father, this is the death that you will die, but first you will suffer many sorrows." Strangely, he will get out of the grave during the night and go back to his mother's house. The poem lines say it that "During the first watch, when the rest of Tubondo was already asleep, Mwindo got out of his grave and crept silently into the house of his mother."(Clyde, 2000) The King Shemwindo and his counselors could not believe it when they saw him there. Now that he ordered his counselors to cut a piece from the trunk of a tree; carve from it the body of a drum; and then put the skin of an antelope in the river to soften for the drumhead, and place this Mwindo in the drum, and seal it tightly so that expert divers to throw him into the watery depths. They did it so but in vain. Maidens coming to fetch water, they saw Mwindo's drum turning round and round in the middle of the pool and heard him "I am saying farewell to Shemwindo, Oh, you ungrateful people, do you think I shall die? The counselors abandoned Shemwindo. He who appears to die but actually will be safe; he is going to encounter Iyangura. In the next lines of the poem, aunt Iyangura will rescue her nephew. She slashed the drumhead and helped him get out of the drum, 
still holding his conga-scepter, his ax, and the little bag with rope in it. This situation matches with two of the characteristics of Otto Rank's mythic- hero's where the baby is put into water in box but later rescued by animals or low peasants.

Following closely, stage four is concerned with mentorship. The hero/heroin is encouraged by a wise mentor who provides them with advice and power, sometimes a magical weapon so that he/she will resist the enemy. Beowulf is not mentored to a great extent but the poem reveals that the Queen empowered him by offering him a cup which he drank probably as power provision The poem lines say that "...the Helming woman went on her rounds, queenly and dignified, decked out rings, offering the goblet to all ranks, treating the household and the assembled troop until it was Beowulf's turn to take it from her hand. With measured words she welcomed the Geat and thanked God for granting her wish that a deliverer she could believe in would arrive to ease their afflictions. Heaney, 2000: 43) Added to this, King Hrothgar's words might reveal a particular wise advice and encouragement to Beowulf as he tells him, "Be on your mettle now, keep in mind your fame, beware of the enemy" before he left him. Similarly, in the Mwindo Epic, Mwindo was nursed by his aunt Iyangura, wife to Mukiti.

Next, the hero passes the first threshold. The hero fully enters the special world of the story for the first time. In Beowulf, this stage matches the situation when Hrothgar leaves Heorot in Beowulf's keeping. It is Beowulf's first time to manage the place that he is not familiar with but as he is driven by exceptional power that made him to come to the Danes help, he will accepts the load. The lines 655- 661 say that "Hrothgar wished Beowulf health and good luck, named him hallwarden and announced: Never, since my hand could hold a shield have I entrusted or given control of the Danes' hall to anyone but you. Ward and guard it, for it is the greatest of houses. Be on your mettle now; keep in mind your fame, and beware of the enemy "(p.45). In the Mwindo Epic, Mwindo's arrival to his aunt's area matches this stage.

Now that the hero/heroin already entered the world of trials, stage six comes where he/she is forced to undergo tests, make allies and enemies in the special world. It is this stage that will train the hero all along his/her quest. Concerning Beowulf, he is ready to fight Grendel as shown from line 688 to 693 that "Then down the brave man lay with his bolster under his head and his whole company of sea-rovers at rest beside him. None of them expected he would ever see his homeland again or get back to his native place and the people who reared him (p.47). Similarly, in the Mwindo Epic, Mwindo faces trials and makes allies and enemies when reaches to Iyangura's. Kasiyembe and Kahungu are among the enemies who are trapping the little-one-just-born-he-walked. Katee is one of the friends he makes as the poem says "Now, Katee the Hedgehog said, "'Mwindo', Kahungu and Kasiyembe are holding secret council against you; they are even preparing pit traps against you, with pointed sticks and razors. But I am Katee, a hedgehog," he continued. "I am going to dig a tunnel for you, a road that begins right here and comes out inside the house of your aunt."(Clyde, 2000) Thus, he will reach to his aunt's thanks to Katee's tunnel and "other unseen helps by Master Spider". Similarly, in his journey to Tubondo where he pursued his father, Mwindo was also helped by Nkuba and Kahindo Kahindo, the daughter of Muisa and guardian of the entrance to the underworld. Clyde (2000) put it that Mwindo was met by Kahindo, the daughter of Muisa and guardian of the entrance $[. .$.$] She cautioned him against going farther: "No$ one ever gets through Muisa's village".

As the journey progresses, the hero comes at last to a dangerous place, often deep underground, where the object of the quest is hidden. Campbell terms this stage the approach to the innermost cave. Regarding Beowulf, this is the Heorot from which Grendel used to attack especially during nights. As discussed in the previous stage, he is waiting for the attack of Grendel and is ready to win a victory over it. In the Mwindo Epic, it is revealed that Kasiyembe, Kahungu and Mukiti plot against him but the Conga he was born with made all those enemies impotent. He would kill them and bring them back to life thanks to this magical tool. Clyde(2000)says, "When Iyangura saw that Mwindo had killed both Mukiti and Kasiyembe, she begged of her nephew to set his heart down; untie his anger and heal her husband and his guardian Kasiyembe; without harboring further resentment."[...] and shortly after Mwindo opened his heart, he wove his congascepter above Kasiyembe and returned him to life, then water returned to the jars, the river was full again, and Mukiti awoke from death."

At the eighth stage, the hero/heroin endures the supreme ordeal. This is a critical moment when the hero/heroin faces the possibility of death, brought to the brink in a fight with a mythical beast. The hero appears to die and is born again. It's a major source of the magic of the hero myth. According to 
Campbell, what happens is that the audience has been led to identify with the hero. We are encouraged to experience the brink-of-death feeling with the hero. We are temporarily depressed, and then we are revived by the hero's return from death. We can see Beowulf is now fighting against Grendel and the latter faces a warrior different from others. In the poem, it is well illustrated that "Venturing closer, his talon was raised to attack Beowulf where he lay on the bed; [...]. The captain of evil discovered himself in a handgrip harder than anything he had ever encountered in any man on the face of the earth. Every bone in his body quailed and recoiled, but he could not escape. He was desperate to flee to his den and hide with the devil's litter, for in all his days he had never been clamped or cornered like this" (Heaney, 2000:51). It follows that Beowulf defeats Grendel as well shown in the lines 813820 that "the monster's whole body was in pain, a tremendous wound appeared on his shoulder, Sinews split and the bonelappings burst. Beowulf was granted the glory of winning; Grendel was driven under the fen-banks, fatally hurt, to his desolate lair. His days were numbered; the end of his life was coming over him. Thus, this fight ends Grendel life in favour of Beowulf who will later be honoured and rewarded for a great deed he has performed.

Mwindo in pursuit of his father, Shemwindo, reflects this stage by which Mwindo risked his life but thanks to Kahindo's advice about what he should; and with the support of Nkuba the lightining god, he survived. The tale reveals that "Mwindo, his aunt, and her servants set off on a war march to Tubondo[...]Mwindo forces were badly beaten, so he called on Nkuba to help, and the lightning hurler unleashed seven bolts against Tubondo[...], But after entering the devastated city, Mwindo soon learned that Shemwindo, his father, had fled before the holocaust, escaping to the underworld realm of Muisa, "the place where no one ever gathers around the fire"(Clyde, 2000). Mwindo is now heading to Mwisa's village where he tasted the worst of his journey. He is given many challenging and fatal tests so as to get his father but overcame them helped and rescued by his Conga, Nkuba the lightning hurler and by Kahindo and Kahungu as well.

The ninth stage is termed seizing the sword where or in other words the reward stage. Having survived death, beaten the dragon, the hero now takes possession of the treasure he has come seeking. Sometimes it is a special weapon like a magic sword or some elixir which can heal the wounded land. For Beowulf, the poem lines reveal that he was thanked, rewarded and his name was praised everywhere. He has now healed the wounds of the Danish people and, indeed, has done what great warriors there failed to do. Hrothgar's words revealed it here: "But now a man, with the Lord's assistance, has accomplished something none of us could manage before now for all our efforts" and expresses her strong feelings of appreciation by saying; "So now, Beowulf, I adopt you in my heart as a dear son". Indeed, Beowulf has played an invaluable role for the Danish King. He will later be presented with precious gifts and is now ready to return back. The poem says the earls' defender furnished the hero with twelve treasures and told him to set out, sail with those gifts safely home to the people he loved, but to return promptly. And so the good and greyhaired Dane, that high-born king, kissed Beowulf and embraced his neck, then broke down in sudden tears (Heaney, 2000: 128) expressing a sad joy as a result of Beowulf's achievement. This is now the road back stage knocking as Beowulf says: Now we who crossed the wide sea have to inform you that we feel a desire to return to Hygelac." As for Mwindo, the traps and tricks of Muisa delayed him but failed. The tale says that Kahungu played an invaluable role revealing Mwindo all about his father's whereabouts. Mwindo finally seizes his father and will return having resurrected Muisa whom he had killed as he had offended him in many ways but in vain. The story has it that "After seizing his father, Mwindo returned to Sheburungu's, telling the god he did not want any of the things he had won during the game. Then Mwindo bid farewell to Sheburungu and tugged on the rope to remind his aunt he was still alive. (Clyde, 2000)

"The road back" stage now takes place and is connected with "Resurrection" stage which entails survival of the hero/heroin. Emerging from the special world, transformed by his/her experience, they once again face death but luckily survive. The hero is not out of the woods yet and is pursued by the vengeful forces from whom he has stolen the treasure. If the hero has not yet managed to reconcile with his father or the gods, they may come raging after him at this point. For Beowulf, this stage is featured by his fight against Grendel's mother that would avenge her only child but in vain. As this time Beowulf fought with bare hands, he would risk his life but later discovered a mighty sword with which he slay Grendel's mother's head and cut the monster's corpse as well shown in the lines 1585- 1590 that Beowulf saw the monster in his resting place, war-weary and wrecked, a lifeless corpse, a casualty of the battle in Heorot. The body gaped at the stroke dealt to it after death: Beowulf cut the corpse's head off (Heaney, 2000: 109). Related to the above situation, Beowulf is on his way back with his troop. He "returned with a sword's 
hilt and Grendel's head" which he now presented to King Hrothgar when he said: "Now, son of Halfdane, prince of the Shieldings, we are glad to bring this booty from the lake. It is a token of triumph and we tender it to you. I barely survived the battle under water. [...] If God had not helped me, the outcome would have been quick and fatal. In the Mwindo Epic, this stage is featured by a hero's triumph return to Tubondo from the Muisa's where he found his father. The story lines say that "Mwindo journeyed back from the underworld, exiting from the Kikoka fern with his father and triumphantly reached Tubondo." Shemwindo's son proves his power after getting his father back. He now resurrected all that passed away as requested by his aunt Iyangura, a deed that ranges him among the mythic heroes than epics'. In line with Otto Rank's theory, a mythic hero finds parents, hero takes revenge on father, father acknowledges hero and is finally honoured. Mwindo does not take revenge to his father. Shemwindo now accepts to be father to Mwindo, a son he did not want at all long before.

The last but most important stage is the "Return with the Elixir". The hero/heroin comes back to the ordinary world, but the adventure would be meaningless unless he/she brought back the elixir, treasure, or some lesson from the special world. Sometimes it's just knowledge or experience, but unless he/she comes back with the elixir or some boon to mankind, he's doomed to repeat the adventure until he does. Beowulf is now ready to return to the ordinary world. $\mathrm{He}$ is well transformed and has learnt a lot from his fight against Grendel as he said to King Hrothgar "Now we who crossed the wide sea have to inform you that we feel a desire to return to Hygelac. Here we have been welcomed and thoroughly entertained. You have treated us well. If there is any favour on earth I can perform beyond deeds of arms, I have done already, anything that would merit your affections more, I shall act, my lord, with alacrity (Heaney, 2000:125). It is a triumph return worth for a heroic figure like Beowulf whose fame spread among the Danes, the Geats and even beyond." and Mwindo, is honoured at this stage. He has reached his goal. He has now got right to life, the right not to be denied a father by the same father who wanted to end his life. He has learnt a many lessons all along his journey. His father now repents and accepts the ills he has committed against the little-one-just-born-he-walked as shown below:

"All you chiefs," Shemwindo stammered, "I don't deny the evil that I have done against my son; indeed, I passed a decree that I would kill all male children. I tried many times to kill this child, but each time, instead of harming him, I only made him stronger. I fled to the underworld thinking I would be safe, but my son set out in search of me; he came to take me away from the abyss of evil in which I was involved. I was at that time withered like dried bananas. And it is like that I arrived here in the village of Tubondo. So may the male progeny be saved. My son has let me see the way in which the dark sky becomes daylight and given me the joy of witnessing again the warmth of the people and of all the things here in Tubondo."( Clyde, 2000)

His father enthrones him and Mwindo is now ruling generously his fathers' people whom he promises he will be caring following the recommendation by five gods videlicet Rain, Moon, Sun, Star and Lightning. Mwindo now wishes his people peace, prosperity, harmony and a happy life; sharing the ups and down in their village. It follows that his fame will stretch in many places. He said it in these words:

\section{"Mwindo then passed good laws for his people, saying, 'May you grow many foods and many crops.May you live in good houses and a beautiful village.Don't quarrel with one another.Don't pursue another's spouse. Don't mock the invalid passing in the village. Accept the chief; fear him; may he also fear you. May you agree with one another, harboring no enmity nor too much hate. May you bring forth tall and short children; in so doing you will bring them forth for the chief". (Clyde, 2000)}

Taken together, the two heroes' journey reflects their power for each. They are led by destiny that they could not escape. Mwindo is more mythic than Beowulf. Biebuyck \& Mateene(1969) account for his fabulous power as he can move on land, in water, underground; has powerful human and supernatural allies including without limitation to his paternal aunt, spiders, bats, lightning; and is equipped by birth with powerful magic objects like conga-scepter by which he copes with all the worst hurdles in his journey. He is also the destroyer of evil forces that could harm him; but also a savior to people and by and large a generous leader. Beowulf is a 
more epic hero than mythic. Although he performs exceptional wanders, his deeds are more human than superhuman. Although the two epics are set for the different communities that produced them, they are both concerned with the quest in the light of Campbell's hero's journey. Mwindo fits more Otto Rank's hero than Beowulf. Both share the feature of being children of distinguished parents. We are not told about Beowulf's birth but Mwindo's is well described. His parents faced difficulties before his extraordinary birth reflected by his climbing up into his mother's belly, then farthering up toward her shoulder, descending down her arm where it was born through the preferred one's middle finger (Clyde, 2000). Although the two stories do not reveal anything about prophecy threatening father, Mwindo's story gives details about how he was put into water in box, a drum, thrown into a pool but later was saved by her aunt's maidens who came to fetch water. Mwindo was now nursed by a lowly woman that is, her aunt Iyangura, and thereafter found his father. Otto's hero takes revenge on father. However, though Mwindo is boastful and aggressive due to his father's perpetrated injustice against him, he did not revenge. Rather, his father acknowledges him and repents by enthroning him. Finally, the hero is honored. It is a long hazardous journey which ends in triumph as he is now ruling his father's people while he was denied life right long before his birth. This happens often times where the hunter becomes the hunted and vice versa. Many literary works including the two epics discussed in this paper reveal how one's life journey is a blend of ups and downs to be endured. One can learn from the two protagonists that "to be heroic is to be courageous enough to die for something; to be inspirational is to be crazy enough to live a little".

\section{CONCLUSION}

This paper focused on the protagonists in two heroic stories namely Beowulf and The Mwindo epic. Three questions guided the study. The first question was about the interface between myths and epic literary genres. Discussion revealed that they are stories about exceptional heroes whose deeds are a good blend of human and superhuman exploits. It is consistent with Scheub (2012) that an epic hero is a visionary who must fight external adversaries; and is often times affected by myth, gods or other divine forces; and is characterized by liminality. The second question was about the extent to which Campbell's heroic journey and Otto Rank's theory of hero-myth apply in the study of Beowulf and
The Mwindo epic; while the third and last question aimed to know the message conveyed through the characters Beowulf and Mwindo. In the light of these questions, the two theories played an invaluable part in the analysis of the two protagonists. The two heroes are affected by many of Campbell's twelve stages of hero's journey but Mwindo is particularly described by Otto Rank's mythic hero characteristics. Taken all in all, the two heroes are extraordinary characters whose exceptional traits range them among other bygone heroic figures led by fate that can be challenged but cannot be altered completely by human powers. One can learn from the two situations that one's rights end where his next door's start and that one can challenge but is unable to alter the destiny of so and so. The two epics also teach humanity that 'genuine heroism lies in persistency'.

\section{REFERENCES}

[1] Abrahams, M., H.(1999). A Glossary of Literary Terms $\left(7^{\text {th }}\right.$ Ed.) Canada: Heile \& Heinle.

[2] Aurobindo, S.(2000).Savitri- numbered Edition. Sri Aurobindo Ashram Trust.

[3] Bazimaziki, G. (2017). Depiction of Human Society through Epic Literary Genres: A Comparative Perspective of theFunction of two African Heroic Epics. International Journal of English and Literature, 8(5), 63-73.

[4] Biebuyck, P. D. (1978). Hero and Chief: Epic Literature from the Banyanga Zaïre Republic. Berkeley: California University Press.

[5] Biebuyck, D. \& Mateene Kahombo C. (Eds \& Trans). (1969). The Mwindo Epic From the Banyanga (Congo Republic), London: UCP.

[6] Cousineau, P.(Ed.) (1990). The Hero's Journey: Joseph Campbell on His Life and Work. New York: Harper and Row. Retrieved from https://www.amazon.com/JOURNEY-JosephCousineau-editor-Campbell/dp/B000I5P70A

[7] Clyde, W. F. (2000). The Hero with an African Face: Mythic Wisdom Africa. Retrieved from https://www.penguinrandomhouse.com/books/54400/thehero-with-an-african-face-by-clyde-w-ford/

[8] Bronzite, D.(n.d).The Hero's Journey- Mythic Structure of Joseph Campbell.(Online). Retrieved fromhttp://www.movieoutline.com/articles/the-hero-journeymythic-structure-of-joseph-campbell-monomyth.html

[9] George, A. (2007). The Epic of Gilgamesh: Thoughts on genre and meaning. 37- 66 .

[10] Heaney, S. (2000). Beowulf: A New verse translation. London: W. W. Norton \&Company.

[11] Kunene, M. (1979).Emperor Shaka the Great, a Zulu Epic. London: Heinmann. 
[12] Mbele, J.(1986) The Hero in the African Epic. USA: UWP.

[13] Rank, O.(n.d) The Myth of the birth of the hero(Online). Retrieved from http://thury.org/Myth/Rank1.html

[14] Rummell, K. (2002). Toni Morrison's "Beloved": Transforming the African heroic epic.The Griot $21: 1$ (Unpublished Paper)

[15] Shepard, A. (2006).No Sons! A Superhero Tale of Africa Retold by Aaron Shepard from theMwindo Epic. Retrieved fromwww.aaronshep.com

[16] Scheub, H.(2012) Trickester and Hero: Two Characters in Oral and Written Traditions of the World. London: UWP.

[17] Toliver, H. (2014). Myth and Epic.Advances in Literary Study, 2, 19-26.

[18] Wright, D. (1957).Beowulf (trans.) New York: Penguin Book. 